\title{
FIRST RECORD OF INTACT EQUISETALEAN STROBILI FROM THE WEALDEN (LOWER CRETACEOUS) OF THE ISLE OF WIGHT, SOUTHERN ENGLAND
}

\author{
CHRISTIAN POTT \\ LWL-Museum für Naturkunde, Westfälisches Landesmuseum mit Planetarium, Sentruper Straße 285, D-48161 Münster, Germany; \\ e-mail: Christian.Pott@lwl.org.
}

Pott, C. (2021): First record of intact equisetalean strobili from the Wealden (Lower Cretaceous) of the Isle of Wight, southern England. - Fossil Imprint, 77(1): 43-52, Praha. ISSN 2533-4050 (print), ISSN 2533-4069 (online).

\begin{abstract}
Two excellently preserved small strobili were obtained from a Wealden plant debris bed in the Lower Cretaceous (Barremian) Wessex Formation, south-east of Chilton Chine, on the Isle of Wight, southern England. The strobili are preserved as compressions and show the characteristic morphology of sporangiophore heads of Equisetales. Based on the morphology of the strobili, attribution to a certain species is not warranted. Therefore, the strobili have been left unassigned in the fossil-genus Equisetostachys which is commonly used for isolated strobili of fossil sphenophytes. From their size, shape and constitution, the strobili are interpreted as immature; the absence of preserved sporangia and spores is consequently not unexpected. Affiliation with Equisetum burchardtii might be an option. The strobili represent the first record of any equisetalean or sphenophyte remains from the Wessex Sub-basin of the English Wealden and are thus of considerable importance. The find is especially significant because previously known specimens from the Weald Sub-basin and the German Wealden are confined to subterranean rhizomes, adventitious roots, tubers and bases of aerial shoots, commonly preserved in situ, together with only fragmentary remains of sporangiophore heads from disarticulated strobili. These strobili finds are thus the first intact equisetalean reproductive structures from the Wealden of either England or Germany.
\end{abstract}

Key words: Equisetostachys, Equisetum burchardtii, Wessex Formation, sphenophyte, horsetail, sporangiophore, strobilus

Received: October 2, 2020 | Accepted: December 18, 2020 | Issued: December 9, 2021

\section{Introduction}

The Isle of Wight, one of the most famous localities for English Wealden fossils, is best known for the richest and most diverse fauna in the Lower Cretaceous of Europe, mainly vertebrates. Some of the very first dinosaur bones were recorded from here (Buckland 1829). The Wealden Group (Wessex Sub-basin) exposed on the Isle of Wight can be subdivided into two units, the Wessex Formation and the overlying Vectis Formation (Sweetman 2011). The Wessex Formation dates from the Berriasian to the Barremian, but only the uppermost (Barremian) part of the formation is exposed on the Isle of Wight. Exposures are confined to two outcrops: a short stretch of coast at Sandown and nearby Yaverland in the south-east and, more extensively, between Shepherd's Chine and Compton Bay in the south-west (Text-fig. 1).

Modest size plant macrofossils, mainly ferns and conifers, are not common but are regularly found and continue to be reported from both outcrops. References to the flora in the older literature include Lindley and Hutton (1833-1835), Carruthers (1867, 1870), Seward (1894, 1895), Scott (1915) and White (1921), although none of these publications represented entirely reliable identifications and attributions, nor were their localities always precise. Interest has resumed more recently again, with extensive collecting and sedimentological studies, including work by Tattersall (1961), Alvin (1974), Hughes (1975), Oldham (1976), Alvin et al. (1981), Watson and Alvin (1996), Sweetman and Insole (2010), Sweetman (2011), Brown et al. (2012) and Price (2017). However, despite this renewed collecting activity, much of it by knowledgeable amateur collectors, most of the Isle of Wight Wealden plants remain in need of authoritative botanical identification and description.

The sparse floral list includes four fern genera: Weichselia STIEHLER and Phlebopteris BRONGn. (often together and fusainised), Onychiopsis M.YокоY. and petrified trunks of Tempskya CoRDA. Conifers are much more prolific, dominated by Pseudofrenelopsis NATH. of the extinct family Cheirolepidiaceae, represented by logs, twigs, leafy shoots, male cones, pollen and female cone scales. Probable araucariaceous conifers include Brachyphyllumtype leafy shoots, seed cones such as those figured by Lindley and Hutton (1833-1835: 153, text-fig. 136) and abundant fragments of wood, often in the form of fusain (charcoalified). Amongst other gymnosperms, most notable 


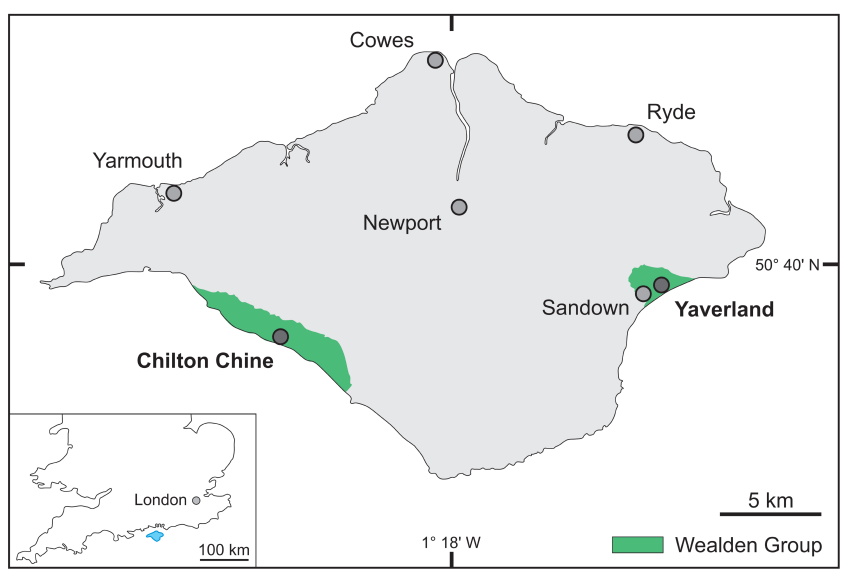

Text-fig. 1. Map of the Isle of Wight with the distribution of the Wealden Group exposed on the south-western and south-eastern coast, showing the fossil localities mentioned in the text (in bold).

are large petrified Cycadeoidea BuCKLAND ex Lind. et HutTon trunks (and fragments), which indicate the presence of bennettitalean plants in the flora. Records of cycadalean and ginkgoalean material require verification by detailed study of leaf cuticles. Reports of equisetaleans have, so far, been lacking from the Isle of Wight.

The majority of recent records from the Isle of Wight (including the strobili described here) constitute plant debris obtained from numerous plant debris beds, which occur throughout the Isle of Wight Wealden beds. Many of them are lenticular in nature and of very limited lateral extent. The abundant spores, pollen and cuticle remains in the plant debris are usually exceptionally well preserved.

In contrast, the English Wealden plants of Berriasian age, mainly obtained from the "Fairlight Clay" of the Hastings Beds in the Weald of Sussex, depict a very diverse flora comprising members of all major plant groups present at that time (Watson and Alvin 1996). Many specimens are large, solid slabs of hard matrix exposing intact plant macrofossils, yielding cuticles in many cases. So far, three equisetalean species have been described (Allen 1941, Watson 1983, Watson and Batten 1990): Equisetum burchardtii DunKer, Equisetites yokoyamae SEWARD and Equisetites lyellii (MANTELL) Morris, none of which have been previously reported from the Isle of Wight. Specimens are comparatively rare in the main flora but Equisetites lyellii is abundant in the soil beds of the younger Wadhurst Clay (Valanginian), where the subterranean rhizomes, adventitious roots and basal portions of aerial shoots occur in situ, overlain by fragment partings containing disarticulated aerial shoots including mature sporangiophore heads with clumps of spores attached. Equisetum burchardtii and Equisetites yokoyamae, known only from a limited number of specimens of narrow rhizome bearing tubers, are probably both from the Berriasian Fairlight Clay. Tubers are unknown in the soil beds. Subterranean parts of the shoots of Equisetum burchardtii are known only from the German Wealden, also Berriasian in age.

Equisetaleans are a group of plants with a worldwide distribution since Palaeozoic times (Boureau 1964). Elgorriaga et al. (2015) recently gave an overview of the present views and opinions of the evolutionary history, taxonomy, phylogenetic relationships, ancient- and presentday distribution as well as diversification and changes in diversity of the group through time. To avoid unnecessary repetition here, I refer to the excellent synopsis by these authors.

Here, two well-preserved equisetalean strobili, obtained from the Wessex Formation at Chilton Chine, Isle of Wight, are reported, which represent the first record of sphenophytes (horsetails) from the Isle of Wight and, to my knowledge, also the first record of intact equisetalean strobili from the English (and German) Wealden. Their potential assignment to species known from the area is discussed below.

\section{Material and methods}

The single specimen yielding two compressed strobili was discovered by private collector Henry Kefford of Washington, Pulborough, West Sussex, in the plant debris bed L6 (the "amber bed"; Sweetman and Insole 2010), on the cliffs south-east of Chilton Chine on the Isle of Wight (Text-fig. 1) in February 2019, and presented to the author for scientific examination. The specimen was subsequently donated by Mr Kefford to the palaeobotanical collections of the LWL-Museum of Natural History, Münster, Germany, where it is curated under accession number WMNM P81019. The two compressed strobili are preserved close to each other, the first slightly overlying the second (P1. 1, Fig. 1), both with their sporophyll heads strikingly picked out by the pale, fine-grained, siltstone sediment between them. To prevent the fossil from eventual destruction through the formation of iron sulphide (pyrite or marcasite), which is common in Wealden fossils from the Isle of Wight, after scientific examination, it was sealed in diffusion resistant ESCAL film together with oxygen absorbers to reduce further decay through chemical reactions.

The specimen was analysed with an Olympus SZX10 stereo-microscope and a Keyence VHX-7000/VH-ZST digital system microscope, and subsequently photographed with a Nikon D750/Nikkor AF-S Mikro 60-mm 1:2.8G ED system digital camera with incident light from various angles to accentuate surface details. To enhance contrast, cross-polarization (i.e., polarized light sources together with an analysing filter in front of the camera lens) was used. In search for spores and cellular details of the sporangiophore heads, the specimen was analysed with a Leica DM5500B transmitting light microscope modified for epifluorescence microscopy at the Palaeobotany Research Group of the Institute of Geology and Palaeontology, Westfälische Wilhelms-Universität, Münster, Germany.

\section{Geological setting}

The amber bed (Sweetman and Insole 2010), exposed on the cliffs of the south coast of the Isle of Wight, is a non-marine sequence within the Lower Cretaceous Wessex Formation, comprising terrestrial, fluvial, lacustrine and lagoonal strata. It forms the lowermost part of the Wealden Group in the Wessex Sub-basin. Palynological, magnetostratigraphic and fossil wood carbon isotope data suggest that the approximately $180 \mathrm{~m}$ thick exposed portion 
of the Wessex Formation is Barremian in age (Sweetman and Martill 2010, Sweetman 2011).

Sediments of the Wessex Formation were deposited by a perennial, meander-belt river system of moderate size with a prevailing flow direction from west to east. Sweetman (2011) provides a detailed and synoptic description and facies interpretation of the Wessex Formation. Insole and Hutt (1994) recognised six major facies associations (see Sweetman 2011) within the Wessex Formation, whereof the lowermost (No. 6) consists of distinctive grey, basally conglomeratic mudstones and siltstones containing abundant plant debris, amongst which the specimen under study here was found.

\section{Systematic palaeobotany}

\author{
Class Equisetopsida C.Agardh, 1825 \\ Order Equisetales DC. ex BERCHT. et J.PresL, 1820 \\ Family Equisetaceae Michx. ex DC., 1804
}

\section{Genus Equisetostachys T.HALle ex M.I.BRICK, 1938 \\ Equisetostachys sp.}

Pls 1,2

De s c ription. The specimen under study comprises two compressed strobili preserved close to each other (P1. 1, Fig. 1). The strobilus in front is preserved in plan view and slightly overlaps the other strobilus, which is preserved in side view. This arrangement, however, is probably caused taphonomically, as is the slight distortion of the strobili through compression of the specimens; no organic connection between the strobili is recognisable. The preserved portions of the roughly round to oval strobili are $25.6 \mathrm{~mm}$ and $23.6 \mathrm{~mm}$ long, respectively, and $22.6 \mathrm{~mm}$ and $25.4 \mathrm{~mm}$ wide. The surface is characterised by the heads of closely packed sporangiophores (Pl. 1, Figs 1, 2, 5; Pl. 2, Figs 1-4, 7). The sporangiophore heads are predominantly hexagonal in outline (Pl. 1, Figs 2, 5; Pl. 2, Figs 3, 4, 7), but several heads, especially in the apical regions of the strobili, are pentagonal in outline (P1. 1, Figs 2, 5; P1. 2, Figs 1, 2). All sporangiophore heads have a flat, central, embossed area (umbo) with a corresponding hexagonal or pentagonal outline (Pl. 2, Figs 3, 4, 6), from the vertices of which an embossed ridge extends to the margin of the sporangiophore head (P1. 2, Figs 4, 6). Densely arranged, tiny scars characterise the surface area of the sporangiophore heads, probably representing the cellular structure (P1. 2, Figs 5, 6, 8 ). Heads preserved in side view do not show any evidence of preserved sporangia, nor are spores discernible, not even with epifluorescence microscopy.

Undistorted sporangiophore heads are up to $4.2 \mathrm{~mm}$ wide and $3.2 \mathrm{~mm}$ long, others, equal in length and width, measure up to $3.4 \mathrm{~mm}$ across. The sporangiophore heads slightly decrease in size towards the apices of the strobili (Pl. 1, Figs 1, 5; P1. 2, Figs 1, 2). The apical-most sporangiophore heads clearly do not constitute a sterile corona or apex such as is visible in the modern species Equisetum hyemale L. (Textfig. $2 \mathrm{a}-\mathrm{c}$ ), nor is there any sign of an annulus, specialised cells forming a collar at the base of the strobilus to aid dehiscence of the sporangiophores in modern Equisetum species (Page 1972). However, this structure may be hidden by the uppermost leaf sheath of the fertile shoot (Text-fig. 2). In the rear strobilus, such a cluster of elongate, cuneate, up to 5-mm-long microphylls is preserved on its reverse side (P1. 1, Figs 3, 4), which corresponds to the location of any potential annulus and the lowermost sporangiophore heads.

Generic assignment. The strobili are assigned to the fossil-genus Equisetostachys that has been erected for isolated sphenophyte strobili consisting of whorls of peltate sporangiophores, and which has been used extensively for such strobili from Mesozoic and Cenozoic deposits (Halle 1908, Brick 1938, Taylor et al. 2009). The complete absence of any characteristic, and therefore easily recognisable, articulated shoots, whorled leaves and branches in the Wessex Formation does not exclude sphenophyte remains to be found, and consequently renders these finds probably the first reports of equisetalean remains from this stratum. No other intact sphenophyte strobili have previously been reported from the English (and German) Wealden, so the presumed affinity of these new strobili relies entirely on gross morphology. The shape, size and close-packed sporophylls (probably in whorls) show remarkable agreement in all visible details with those of several extant (Text-fig. 2) and fossil Equisetites/Equisetum species (see discussion below); therefore, the assignment to Equisetostachys seems most appropriate.

Referral to a particular species of Equisetites or Equisetum will only be possible if relevant sterile material or sporangiophores with spores are discovered and prove conspecific with the strobili. Differences between the two genera have been extensively discussed (e.g., Harris 1961, Watson and Batten 1990, Stanich et al. 2009), and revealed that identification of diagnostic characters, which clearly distinguish fossil Equisetites species from extant Equisetum, remains unresolved. Many of the fossil representatives of these genera have been suggested as belonging to the same evolutionary lineage leading to the extant horsetails. However, Equisetites lyellii displays features which suggest it belongs to a previously unknown, extinct sub-genus (Watson and Batten 1990). Therefore, the generic identity of species assigned to Equisetites is probably not as ambiguous and arbitrary as is sometimes suggested.

\section{Interpretation}

Developing strobili of modern Equisetum species, such as Equisetum hyemale, show densely packed, commonly apically connate, penta- to hexagonal peltate sporangiophore heads (Text-fig. 2a-c) which fully open for spore release by elongation of the strobilus axis only when the spores are mature (Text-fig. 2d). Usually, once the spores are ready for dispersal, equisetalean strobili expand to release them, induced by elongation of the strobilus axis and desiccation processes. If the sporangia and spores in the Isle of Wight strobili under study here were not yet fully developed, this would explain their absence as their delicate developing tissues might not have possessed preservational potential. The adpressed microphylls covering the annulus might also indicate the strobili were in the process of developing. Taking into account the tightly packed and spherical (rather 

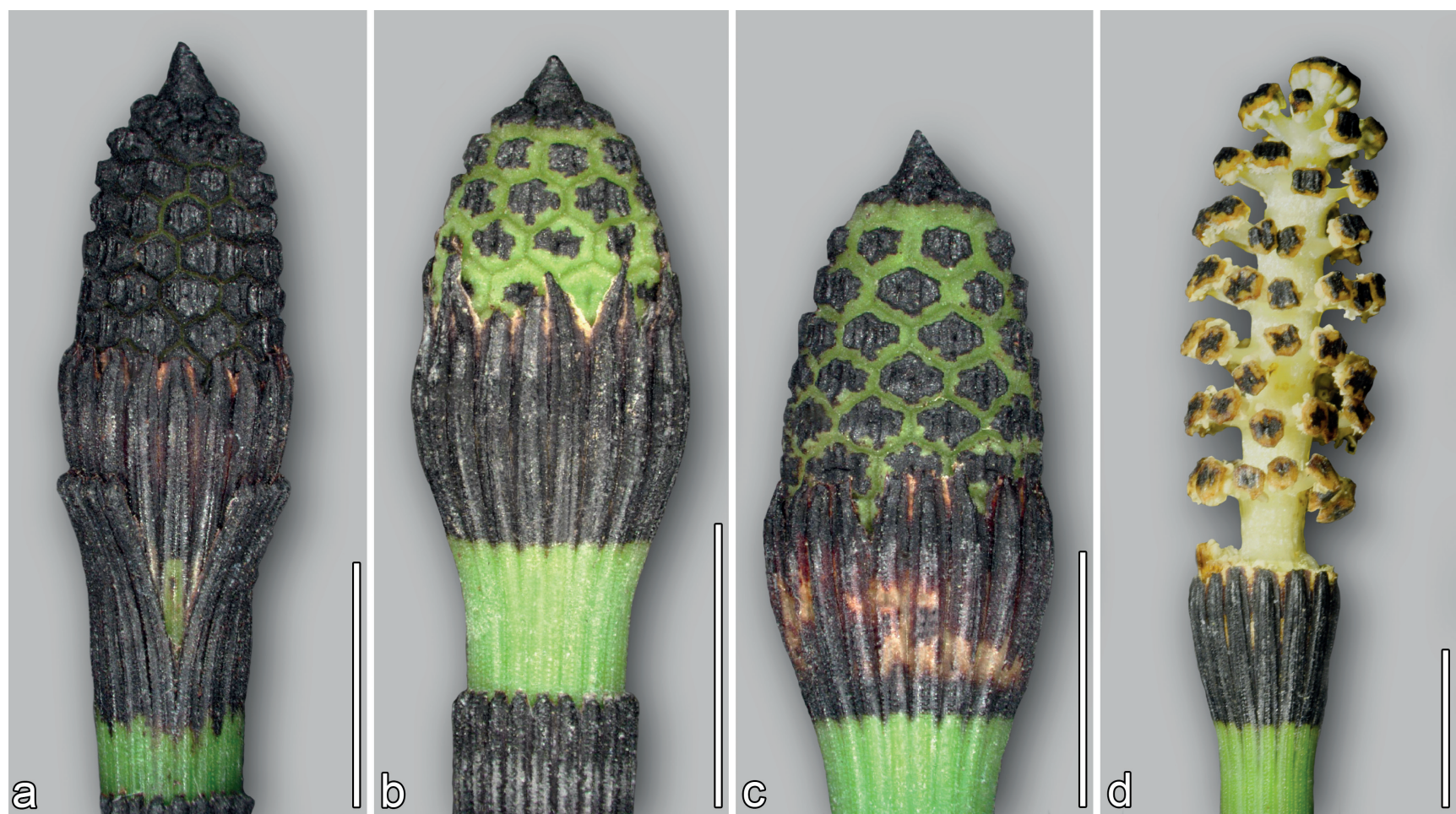

Text-fig. 2. Strobili of modern Equisetum hyemale L. in different stages of expansion/maturation. Living specimens from near Billerbeck in Westphalia, Germany. Scale bars 5 mm.

than elongate) morphology of the strobili, the absence of preserved sporangia and spores, and the adpressed microphylls covering the annulus, the strobili are interpreted as immature.

It is not unexpected that the fossil strobili are disarticulated from any shoot fragments, given the commonly fragile articulate architecture of equisetalean plants, particularly in deciduous species. Rapid disintegration at the nodes produces portions such as microphylls, leaf sheaths, aerial shoot fragments and strobili, while subterranean (in situ) remains are commonly preserved intact due to their permanent subterranean position in life. Whether both the new strobili originate from a single individual remains unclear. However, when comparing with modern species such as Equisetum hyemale or Equisetum arvense L., which every now and then also produce several spherical rather than elongate strobili in the apical region of a single aerial shoot (interpreted as atavism, e.g., Krings 1999), it may well be possible that the two strobili under study here derive from the same individual.

\section{Comparisons and discussion}

\section{Comparison with Early Cretaceous species}

Comparison of the Isle of Wight Equisetostachys strobili with other Wealden equisetalean strobili initially seems impossible since, to my knowledge, no other intact strobili are known. However, the fragment partings above the Weald Sub-basin soil beds provide convincing evidence of disaggregated strobili, which, almost without doubt, must belong to Equisetites lyellii (Watson and Batten 1990) and are thus the only candidate for comparison. However, the peltate sporangiophore heads of Equisetites lyellii are round in shape with about 24 densely arranged surface ribs radiating from a central depression, which is quite different from the Isle of Wight Equisetostachys and also unlike modern species, in which they are penta-/hexagonal as the result of close-packing. Equisetites lyellii sporangiophores are also different in having a smooth distal surface, lacking both the rough surface pattern and the flat umbo present on the sporangiophore heads of the Isle of Wight strobili. The speculative reconstruction of the strobilus of Equisetites lyellii presented by Watson and Batten (1990: fig. 67), based on the known sporophylls, looks very different from Equisetostachys.

The two other species known from the Wealden of England and north-western Germany include the poorly known Equisetites yokoyamae and the common Equisetum burchardtii (known in more detail from the German Wealden; Dunker 1846, Ettingshausen 1852, Schenk 1871, Watson and Batten 1990, Pott et al. 2014, Pott 2019). The latter was assigned to Equisetum, somewhat reluctantly, by Watson and Batten (1990: 38), because the authors found the in situ rhizomes, tubers and subterranean parts of aerial shoots to be "so similar to living species of the genus Equisetum that it is difficult to imagine any generic differences", although it should be noted that anatomical details of the above-ground parts of Equisetum burchardtii are not available, and the reproductive organs are unknown. A few, poorly preserved aerial shoots of Equisetum burchardtii were reported by Dunker (1846), but also here the reproductive organs remain unknown. Based on this assumption, Watson and Batten (1990: 41) again provided a speculative restoration of Equisetum burchardtii, in which the known subterranean portions are completed with the most likely above-ground features typical of modern representatives of this subgenus 
(Page 1972) such as solid, strongly angular branches distinct from the main axis and with elongate strobili with rounded apices and penta-/hexagonal sporangiophore heads.

If it is assumed that the new Equisetostachys strobili were flattened during preservational processes, but were round in cross section when alive, their diameter would have been about 14 and $16 \mathrm{~mm}$, respectively. Considering the diameter of known Equisetum burchardtii aerial shoots (up to $5 \mathrm{~mm}$ ), it is not impossible that the strobili from the Isle of Wight belong to this species.

With regard to species reported from the Lower Cretaceous of other regions than the English and German Wealden, most of them are known from subterranean plant portions, such as rhizomes, adventitious roots and tubers, and from a limited number of aerial shoots only (e.g., Srebrodolskaya 1983, Stanich et al. 2009, Sun et al. 2013), rendering further comparisons impossible.

\section{Comparison with other Mesozoic species}

The strobili of Equisetites arenaceus (JAEGER) SCHENK from the Carnian (Upper Triassic) of several localities in southern Germany and from Lunz am See, Austria (Kelber and Van Konijnenburg-van Cittert 1998, Pott et al. 2008, 2018), are identical in superficial structure and shape, but are some 1.5-2 times larger in all dimensions than the Isle of Wight strobili; furthermore, the stems of Equisetites arenaceus are 4-12 cm wide (Pott et al. 2008), much larger than any Wealden species. Moreover, the strobili of Equisetites arenaceus are produced in clusters of up to three strobili on short, deciduous, aerial shoots or lateral branches, which are shed as a whole (Kelber and Van Konijnenburg-van Cittert 1998).

Strobili referred to Equisetostachys include Equisetostachys nathorstii T.HALLE and Equisetostachys suecicus (NATH.) T.Halle from the Rhaetian - Hettangian (Upper Triassic) of Höganäs and Höör in Scania, Sweden (Halle 1908), and Equisetostachys sibiricus (HEER) M.I.BrICK from the Middle Jurassic of Ust'-Baley, Siberia, Russia (Kryshtofovich 1933, Brick 1938); all species have peltate sporangiophores with hexagonal heads and a sculptured surface. Strobili of Equisetostachys suecicus were approximately $40 \mathrm{~mm}$ long and $20 \mathrm{~mm}$ wide with a cylindrical shape; sporangiophore heads, $2.0-3.0 \mathrm{~mm}$ in diameter, have a hexagonal umbo, which is connected through embossed ridges with the vertices of the hexagonal margins of the heads (Halle 1908). Likewise, Equisetostachys sibiricus has similar hexagonal sporangiophore heads with a central umbo, but the strobilus is spherical (Brick 1938).

Equisetites muensteri STERnB. from the Rhaetian of Jameson Land, Greenland, is known from expanded and developing (unexpanded) strobili with peltate sporangiophores with a hexagonal pattern on the heads similar to that of the Isle of Wight strobili (Harris 1931), but the sporangiophore heads of Equisetites muensteri, however, are considerably smaller; being only $2.3-2.9 \mathrm{~mm}$ in diameter.

Sporangiophore heads of Equisetum columnare BRONGN., described by Harris (1961) from the Bajocian (Middle Jurassic) of Yorkshire, England, are identical in size, shape and surface structures to the sporangiophore heads of the Isle of Wight strobili. However, no intact strobili are known from Equisetum columnare. Similar equisetalean strobili with well-preserved sporangiophore heads akin to those of the Isle of Wight strobili are also known from the Lower Jurassic of Chubut Province, Patagonia, Argentina, described as Equisetum dimorphum Elgorriaga, Escapa, Bomfleur, Cúneo et OtTone (Elgorriaga et al. 2015).

\section{Conclusion}

Sporangiophore heads of Equisetaceae seem to show comparatively highly conservative features such as their morphology and (outer) surface patterns rendering them rather uninformative and less useful with regard to species identification. Consequently, the specific identification of the strobili from the Wealden of the Isle of Wight can only be achieved when both sterile and fertile material is found in the same bedding planes, either attached or convincingly belonging to the same parent plant.

\section{Acknowledgements}

Hans Kerp from the Palaeobotany Research Group at the University of Münster is thanked for facilitating examination of the specimen with an epifluorescence microscope. HeinzOtto Rehage of the LWL-Museum of Natural History, Münster, is thanked for his help in accessing living material of Equisetum hyemale. I am grateful to Joan Watson, London, and Mihai Popa, Bucharest, for their detailed reviews of the manuscript.

\section{References}

Agardh, C. A. (1825): Aphorismi botanici. - Berling, Lund, $246 \mathrm{pp}$.

Allen, P. (1941): A Wealden soil bed with Equisetites lyelli (Mantell). - Proceedings of the Geologists' Association, 52: $362-374$. https://doi.org/10.1016/S0016-7878(41)80015-7

Alvin, K. L. (1974): Leaf anatomy of Weichselia based on fusainized material. - Palaeontology, 17: 587-598.

Alvin, K. L., Fraser, C. J., Spicer, R. A. (1981): Anatomy and palaeoecology of Pseudofrenelopsis and associated conifers in the English Wealden. - Palaeontology, 24: 759-778.

Berchtold, F. Graf von, Presl, J. S. (1820): O přirozenosti rostlin aneb rostlináŕ [About the nature of plants, or Planter]. - Karel Wiljm Enders, Praha, 322 pp. (in Czech)

Boureau, E. (1964): Traite de Paleobotanique, Tome III, Sphenophyta, Noeggerathiophyta. - Masson et Cie., Paris, $544 \mathrm{p}$.

Brick, M. I. (1938): Mezozoyskaya flora Yuzhnoy Fergany II / La flore mésozoïque du Ferghana meridional. II. Fougères (fin), Equisétinées. - Trudy Sredneaziatskogo Geologicheskogo Tresta, 3: 1-74.

Brown, S. A. E., Scott, A. C., Glasspool, I. J., Collinson, M. E. (2012): Cretaceous wildfires and their impact on the Earth system. - Cretaceous Research, 36: 162-190. https://doi.org/10.1016/j.cretres.2012.02.008

Buckland, W. (1829): On the Cycadeoideae, a family of fossil plants found in the oolite quarries of the Isle of 
Portland. - Transactions of the Geological Society of London, Series 2(2): 395-401.

https://doi.org/10.1144/transgslb.2.3.395

Candolle, A.-P. de (1804): Essai sur les propriétés médicales des plantes, comparées avec leurs formes extérieures et leur classification naturelle. - Didot Jeune, Paris, 148 pp. https://doi.org/10.5962/bhl.title.112422

Carruthers, W. (1867): On some cycadean fruits from the secondary rocks of Britain. - The Geological Magazine, 4: 101-106. https://doi.org/10.1017/S001675680020527X

Carruthers, W. (1870): On fossil cycadean stems from the secondary rocks of Britain. - Transactions of the Linnean Society of London, 26: 675-708.

https://doi.org/10.1111/j.1096-3642.1870.tb00201.x

Dunker, W. (1846): Monographie der norddeutschen Wealdenbildung: Ein Beitrag zur Geognosie und Naturgeschichte der Vorwelt. - Oehme und Müller, Braunschweig, 83 pp. https://doi.org/10.24355/dbbs.084-201506241129-0

Elgorriaga, A., Escapa, I. H., Bomfleur, B., Cúneo, R., Ottone, E. G. (2015): Reconstruction and phylogenetic significance of a new Equisetum Linnaeus species from the Lower Jurassic of Cerro Bayo (Chubut Province, Argentina). - Ameghiniana, 52: 135-152.

https://doi.org/10.5710/AMGH.15.09.2014.2758

Ettingshausen, C. von (1852): Beitrag zur Flora der Wealdenperiode. - Abhandlungen der Kaiserlich-Königlichen Geologischen Reichsanstalt, Wien, 1: 1-32.

Halle, T. G. (1908): Zur Kenntnis der mesozoischen Equisetales Schwedens. - Kungliga Svenska Vetenskaps-Akademiens Handlingar, 43: 1-56.

Harris, T. M. (1931): The fossil flora of Scoresby Sound, East Greenland, part 1: Cryptogams (exclusive of Lycopodiales). - Meddelelser om Grønland, 85: 1-104.

Harris, T. M. (1961): The Yorkshire Jurassic flora. I. Thallophyta-Pteridophyta. - Trustees of the British Museum (Natural History), London, $\mathrm{x}+212 \mathrm{pp}$. https://doi.org/10.5962/bhl.title.118957

Hughes, N. F. (1975): Plant succession in the English Wealden strata. - Proceedings of the Geological Association, 86: 439-455. https://doi.org/10.1016/S0016-7878(75)80058-7

Insole, A. N., Hutt, S. (1994): The palaeoecology of the dinosaurs of the Wessex Formation (Wealden Group, Early Cretaceous), Isle of Wight, southern England. - Zoological Journal of the Linnaean Society, 112: 197-215. https://doi.org/10.1111/j.1096-3642.1994.tb00318.x

Kelber, K.-P., Van Konijnenburg-van Cittert, J. H. A. (1998): Equisetites arenaceus from the Upper Triassic of Germany with evidence for reproductive strategies. - Review of Palaeobotany and Palynology, 100: 1-26. https://doi.org/10.1016/S0034-6667(97)00061-4

Krings, M. (1999): Ein aberranter, fertiler Sommersproß von Equisetum arvense L. aus der Umgebung von Münster (Westfalen). - Natur und Heimat, 59: 33-41.

Kryshtofovich, A. N. (1933): Angarskaya svita Baykal'skiy otdel [Baikal Formation of the Angara Group]. - Trudy Vsesoyuznogo geologo-razvedochnogo Obedinenya NKTP SSSR, 326: 1-136. (in Russian)

Lindley, J., Hutton, W. (1833-1835): The fossil flora of Great Britain; or, figures and descriptions of the vegeta- ble remains found in a fossil state in this country. Volume II. J. Ridgeway and sons, London, xxviii +208 pp. https://doi.org/10.5962/bhl.title. 149330

Oldham, T. C. B. (1976): Flora of the Wealden plant debris beds of England. - Palaeontology, 19: 437-502.

Page, C. N. (1972): An interpretation of the morphology and evolution of the cone and shoot of Equisetum. - Botanical Journal of the Linnean Society, 65: 359-397. https://doi.org/10.1111/j.1095-8339.1972.tb02279.x

Pott, C., Kerp, H., Krings, M. (2008): Sphenophytes from the Carnian (Upper Triassic) of Lunz am See, Lower Austria. - Jahrbuch der Geologischen Bundesanstalt, Wien, 148: 183-199.

Pott, C. (2019): Plant fossils from the Wealden facies (Lower Cretaceous, Berriasian) of Tecklenburg, Westphalia, Germany. - Neues Jahrbuch für Geologie und Paläontologie, Abhandlungen, 294: 213-228. https://doi.org/10.1127/njgpa/2019/0854

Pott, C., Bouchal, J. M., Choo, T. Y. S., Yousif, R., Bomfleur, B. (2018): Ferns and fern allies from the Carnian (Upper Triassic) of Lunz am See, Lower Austria: A melting pot of Mesozoic fern vegetation. - Palaeontographica, B, 297: 1-101. https://doi.org/10.1127/palb/2018/0059

Pott, C., Guhl, M., Lehmann, J. (2014): The Early Cretaceous flora from the Wealden facies at Duingen, Germany. - Review of Palaeobotany and Palynology, 201: 75-105. https://doi.org/10.1016/j.revpalbo.2013.10.002

Price, T. (2017): Recent finds and research. - Website of "Dinosaur Isle", http://www.dinosaurisle.com/recent finds.aspx; accessed 29 September 2020.

Schenk, A. (1871): Die fossile Flora der nordwestdeutschen Wealdenformation. - Fischer, Kassel, 66 pp.

Scott, D. H. (1915): A famous Isle of Wight fossil plant. Hampshire Studies: Proceedings of the Hampshire Field Club and Archaeological Society, 7(2): 19-32.

Seward, A. C. (1894): The Wealden flora. Part I. Thallophyta-Pteriodophyta. Catalogue of Mesozoic plants in the Department of Geology. - British Museum (Natural History), London, xi $+179 \mathrm{pp}$. https://doi.org/10.5962/bhl.title. 17318

Seward, A. C. (1895): The Wealden flora. Part II. Gymnospermae. Catalogue of Mesozoic plants in the Department of Geology. - British Museum (Natural History), London, xii $+259 \mathrm{pp}$. https://doi.org/10.5962/bhl.title.17318

Srebrodol'skaya, I. N. (1983): Dva novykh rannemelovykh vida roda Equisetum (Equisetaceae) iz Zabaykal'ya [Two new Early Cretaceous species of the genus Equisetum (Equisetaceae) from the Transbaikal Area]. - Botanicheskii Zhurnal, 68(9): 1249-1254. (in Russian)

Stanich, N. A., Rothwell, G. W., Stockey, R. A. (2009): Phylogenetic diversification of Equisetum (Equisetales) as inferred from Lower Cretaceous species of British Columbia, Canada. - American Journal of Botany, 96: 12891299. https://doi.org/10.3732/ajb.0800381

Sun, B.-N., Du, B.-X., Ferguson, D. K., Chen, J.-L., He, Y.L., Wang, Y.-D. (2013): Fossil Equisetum from the Lower Cretaceous in Jiuquan Basin, Gansu, Northwest China 
and its paleoclimatic significance. - Palaeogeography, Palaeoclimatology, Palaeoecology, 385: 202-212.

https://doi.org/10.1016/j.palaeo.2013.06.005

Sweetman, S. C. (2011): The Wealden of the Isle of Wight. In: Batten, D. J. (ed.), English Wealden fossils (Palaeontological Association Field Guide to Fossils 14). The Palaeontological Association, London, pp. 52-78.

Sweetman, S. C., Insole, A. N. (2010): The plant debris beds of the Early Cretaceous (Barremian) Wessex Formation of the Isle of Wight, southern England: Their genesis and palaeontological significance. - Palaeogeography, Palaeoclimatology, Palaeoecology, 292: 409-424. https://doi.org/10.1016/j.palaeo.2010.03.055

Sweetman, S. C., Martill, D. M. (2010): Pterosaurs of the Wessex Formation (Early Cretaceous, Barremian) of the Isle of Wight, southern England: A review with new data. - Journal of Iberian Geology, 36: 225-242. https://doi.org/10.5209/rev JIGE.2010.v36.n2.9

Tattersall, J. A. (1961): Notes on Onychiopsis psilotoides
(Stokes \& Webb). - Annals and Magazine of Natural History, 13: 349-352.

https://doi.org/10.1080/00222936108651116

Taylor, T. N., Taylor, E. L., Krings, M. (2009): Paleobotany: The biology and evolution of fossil plants. - Academic Press, Elsevier, Burlington, MA, Amsterdam, xxii + $1230 \mathrm{pp}$.

Watson, J. (1983): Two Wealden species of Equisetum found in situ. - Acta Palaeontologica Polonica, 28: 265-269.

Watson, J., Alvin, K. A. (1996): An English Wealden floral list, with comments on possible environmental indicators. - Cretaceous Research, 17: 5-26. https://doi.org/10.1006/cres.1996.0002

Watson, J., Batten, D. J. (1990): A revision of the English Wealden flora, II. Equisetales. - Bulletin of the British Museum of Natural History, 46: 37-60.

White, H. J. O. (1921): A short account of the geology of the Isle of Wight (Memoirs of the Geological Survey). London, British Geological Survey, 219 pp. 


\section{Explanations of the plates}

\section{PLATE 1}

Equisetostachys strobili from the Isle of Wight, specimen WMNM P81019

1. The specimen in front view with the two strobili preserved close to each other.

2. Rear strobilus preserved in side view (photographed from front), note the arrangement of the penta- to hexagonal sporangiophore heads.

3. Same strobilus photographed from reverse side, note the cluster of elongate, cuneate microphylls at its proximal end (arrowheads).

4. Enlarged view of the cluster of elongate, cuneate microphylls (arrowheads).

5. Front strobilus preserved in plan view, note the apex of the strobilus and the surface pattern of the sporangiophore heads.

Scale bars $5 \mathrm{~mm}$.

\section{PLATE 2}

Detail views of Equisetostachys strobili from the Isle of Wight, specimen WMNM P81019 (left column: the rear strobilus, right column: the front strobilus)

1,2 . Close-up of the edge or apical regions.

3,4 . Details of the surface of the sporangiophore heads, note the umbo and the ridges.

5 , 8. Close-up of the umbo, note the visible cellular structure and the ridges extending from the vertices of the umbo to the margin of the sporangiophore head (arrowheads).

6. Close-up of a sporangiophore head, note the umbo, the scars or surface pattern and the ridges extending from the vertices of the umbo to the margin of the sporangiophore head (arrowheads).

7. Detail of the sporangiophore heads preserved on the reverse side of the rear strobilus.

Scale bars $1 \mathrm{~mm}$. 
PLATE 1
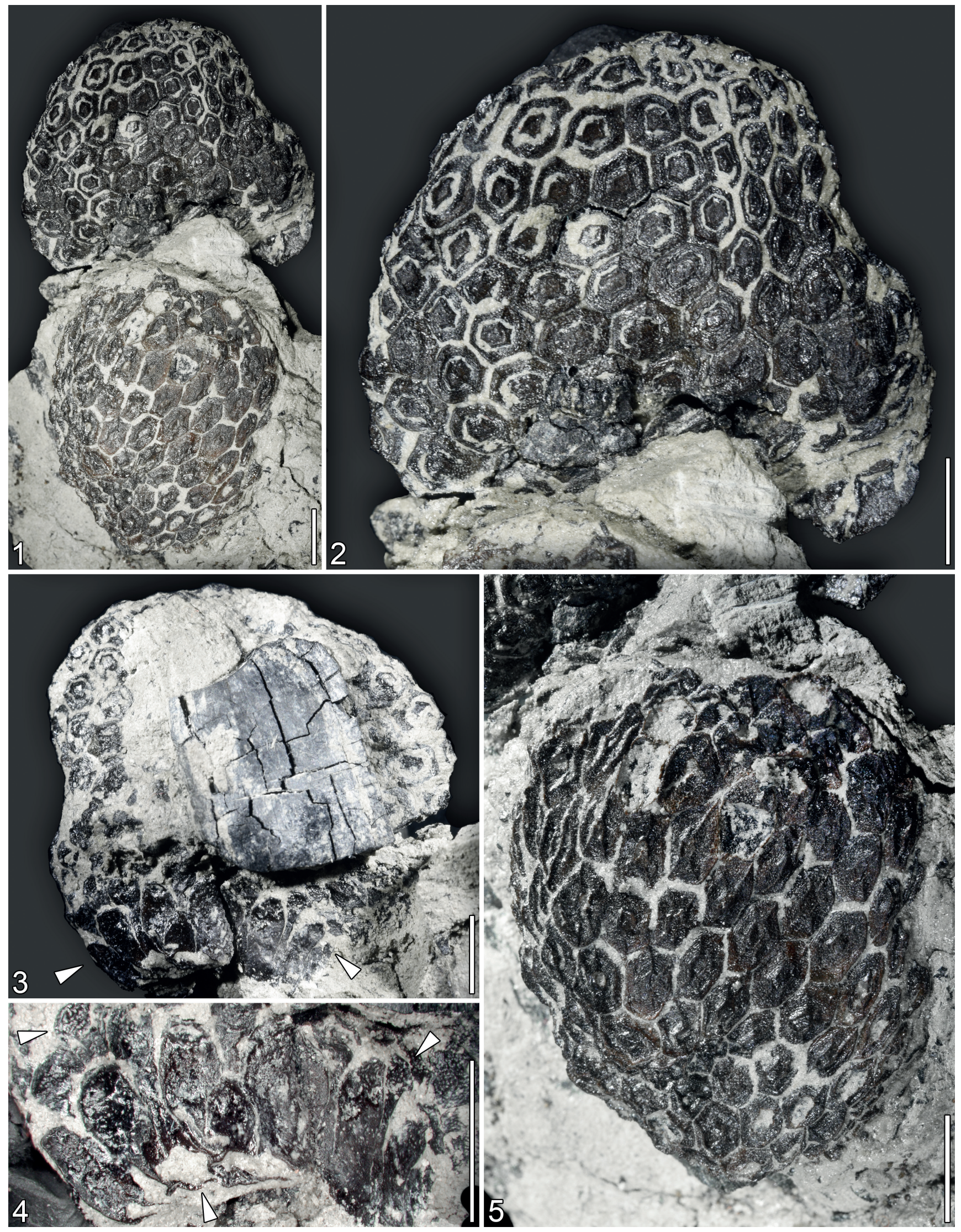
PLATE 2

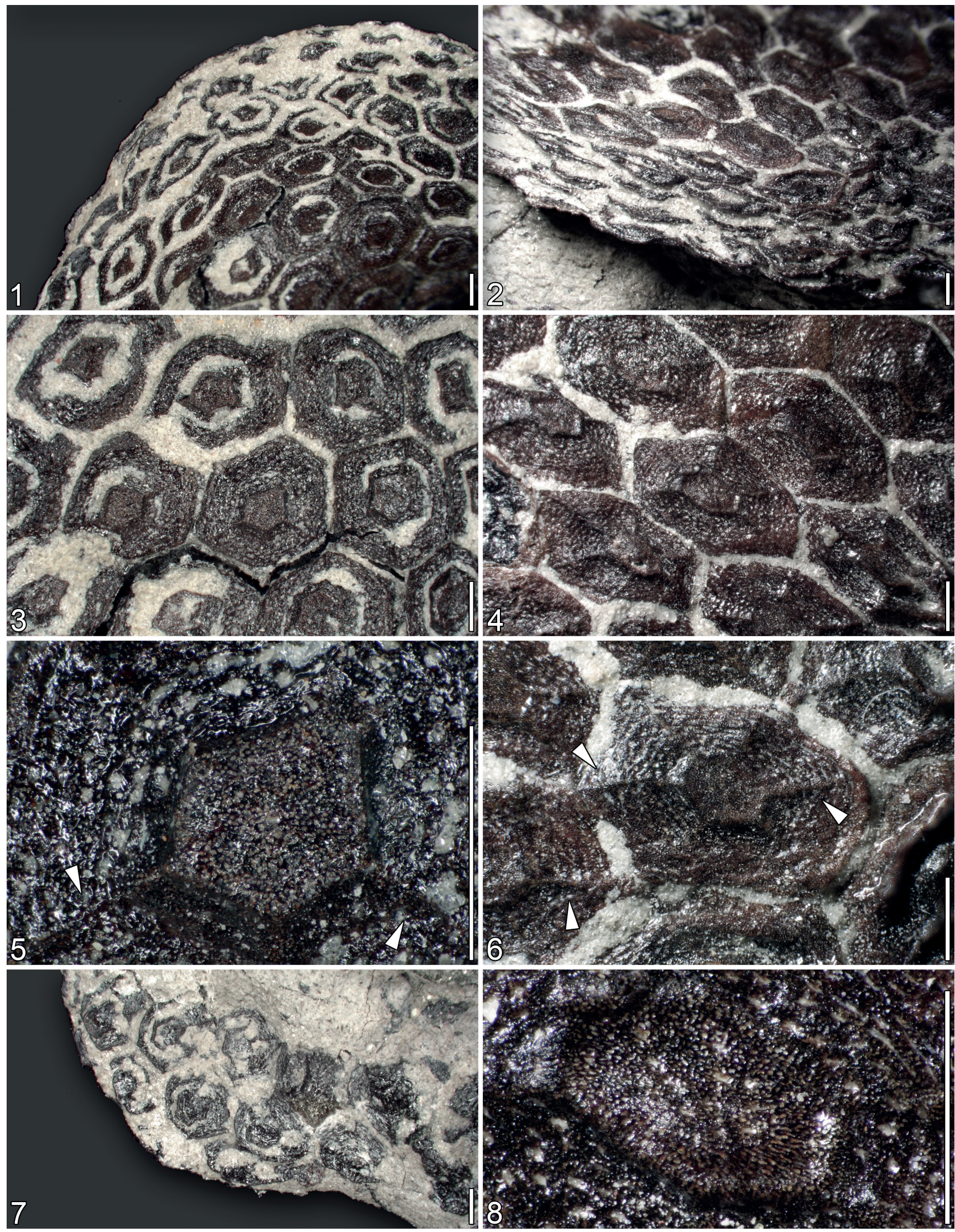

